\title{
Optimalisasi Pelaporan Standar Pelayanan Minimal Gawat Darurat Berbasis Teknologi Informasi
}

\author{
Kori Puspita Ningsih ${ }^{1}$, Sigid Nugroho Adhi ${ }^{2}$ \\ Universitas Jenderal Achmad Yani Yogyakarta ${ }^{1-2}$ \\ Jl.Brawijaya, Ringroad Barat, Ambarketawang, Gamping, Sleman, Indonesia \\ Email: puspitakori@gmail.com ${ }^{1}$, hanyasigid@gmail.com²
}

\begin{abstract}
ABSTRAK Rumah sakit sebagai Badan Layanan Umum Daerah (BLUD)
wajib memenuhi Standar Pelayanan Minimal Rumah Sakit (SPM RS). Pengukuran tolok ukur mutu pelayanan rumah sakit pada Standar Nasional Akreditas Rumah Sakit juga dapat dinilai melalui SPM RS. Pada tahun 2019 RSUD Panembahan Senopati Bantul menetapkan fokus peningkatan mutu pada pelayanan gawat darurat. Dalam pembuatan laporan SPM GD membutuhkan data yang cukup heteragon, tersebar dibanyak tempat dan belum real time. Apabila kualitas pelaporan SPM GD kurang baik maka akan mempengaruhi kualitas pelaporan SPM RS yang kurang baik pula. Hal ini tentunya akan mencerminkan kinerja rumah sakit. Metode dalam kegiatan Pengabdian Kepada Masyarakat ini adalah difusi ipteks yang digunakan dalam rangka pelatihan pemanfaatan aplikasi SPM GD berbasis web. Sebelum dilakukan pelatihan, diberikan penyuluhan mulai dari proses pengumpulan, pengolahan dan penyajian laporan SPM GD. Kegiatan pengabdian berjalan lancar. Pada awalnya, register gawat darurat yang dihasilkan dari Sistem Informasi Rumah Sakit tidak dimanfaatkan sebagai bahan pengumpulan data SPM GD. Dengan adanya kegiatan penyuluhan dan pelatihan ini, dapat disimpulkan akhirnya petugas menyadari pentingnya pemanfaatan teknologi informasi untuk meningkatkan kualitas pelaporan SPM GD pada aspek ketersediaan, kemudahan, kesesuaian, kelengkapan dan ketepatan waktu dalam rangka meningkatkan efektifitas alur kerja petugas, kemudahan mengakses informasi, dan penyimpanan data terpusat pada manajamen basis data.
\end{abstract}

\section{KATA KUNCI: standar pelayanan minimal; teknologi informasi}

ABSTRACT Hospitals as Regional Public Service Agencies are required to meet Hospital Minimum Service Standards. Measurement of hospital service quality benchmarks on the National Hospital Accreditation Standards can also be assessed through the RS SPM. In 2019 Panembahan Senopati Bantul District Hospital focuses on improving quality in emergency services. In making SPM reports $G D$ requires sufficient heterogony data, spread in many places, and not in real-time. If the quality of the SPM GD report is not good, it will affect the quality of the RS SPM reporting which is also not good. This will reflect the importance of the hospital. The methods in this Community Service Activities differ in the science and technology used in the context of training to use the web-based GD SPM application. Before the training, counseling was given starting from the process of collecting, processing, and presenting GD SPM reports. Community service activities went smoothly. Initially, the emergency department register generated from the Hospital Information System was not used as material 
obtained by GD SPM data. After counseling and training, it can be conclude that in the end of the officer finally resolves the problem of using information technology to improve the quality of GD SPM reporting based on approval, convenience, suitability, completeness, and timeliness to improve the effectiveness of the workflow of officers, obtain information, and store data centrally on database management.

\section{KEYWORDS: minimum service standards; information technology}

\section{Pendahuluan}

Rumah sakit sebagai Badan Layanan Umum Daerah (BLUD) mempunyai kewajiban membuat dan menyampaikan dokumen sebagai syarat administrasi, yang salah satu adalah Standar Pelayanan Minimal (SPM) [1]. Hal ini juga dipertegas kembali dalam [1] bahwa standar pelayanan minimal memuat batasan minimal mengenai jenis dan mutu layanan dasar yang harus dipenuhi oleh SKPD atau Unit Kerja. Adanya SPM RS sebagai tolok ukur pengukuran mutu pelayanan rumah sakit juga didukung oleh Standar Nasional Akreditasi Rumah Sakit (SNARS) pada standar Peningkatan Mutu dan Keselamatan Pasien (PMKP) 6 yang menjelaskan bahwa setiap unit kerja di RS memilih dan menetapkan indikator mutu yang dipergunakan untuk mengukur mutu unit kerja. Indikator mutu unit kerja tersebut dapat menggunakan indikator mutu yang tercantum di dalam Standar Pelayanan Minimal (SPM) [2].

Standar pelayanan minimal merupakan ketentuan tentang jenis dan mutu pelayanan dasar urusan wajib daerah yang berhak diperoleh setiap warga negara secara minimal[3]. SPM digunakan sebagai acuan atau ketentuan daerah dalam melaksanakan perencanaan pelaksanaan dan pengendalian serta pengawasan dan pertanggungjawaban penyelenggaraan standar pelayanan minimal rumah sakit.

RSUD Panembahan Senopati Bantul merupakan BLUD milik Pemerintah Kabupaten Bantul, dengan jenis rumah sakit tipe B. Standar Pelayanan Minimal Gawat Darurat (SPM GD) dibutuhkan oleh kepala Seksi Mutu dan Audit Klinik serta Pimpinan Tingkat Atas RSUD Panembahan Senopati sebagai bahan pembuatan SPM RS [4]. Informasi capaian SPM GD dipergunakan sebagai bahan pertimbangan dalam penentuan arah kebijakan dan perbaikan sistem pelayanan kesehatan di RSUD Panembahan Senopati Bantul.

Masalah yang dihadapi RSUD Panembahan Senopati Bantul adalah pembuatan laporan SPM GD membutuhkan data yang cukup heteragon, tersebar dibanyak tempat dan belum real time, sehingga dibutuhkan peran sistem informasi. Sistem informasi dapat meningkatkan proses organisasi. Sistem informasi mengotomatiskan banyak tahap pada proses-proses yang ada di organisasi yang sebelumnya dilakukan secara konvensional [5]. Kebutuhan pengguna akan pengembangan sistem, yaitu sistem yang mampu mendukung dalam pengolahan data dan dapat menyajikan informasi yang jelas, serta langsung dapat diakses oleh manajerial [6].

Saat ini RSUD Panembahan Senopati Bantul sudah menggunakan sistem informasi, namun masih terbatas pada modul untuk kepentingan billing system pasien, sehingga kebutuhan data dan pelaporan dalam upaya peningkatan mutu belum terfasilitasi. Sistem informasi pelaporan standar pelayanan minimal gawat darurat berbasis web diujikan di RSUD Tipe B wilayah DIY dan menunjukkan sistem mampu memenuhi kebutuhan pengguna [7].

Pentingnya pelaporan SPM GD sebagai bahan pembuatan laporan SPM RS dan tolak ukur kinerja pelayanan gawat darurat dapat dioptimalkan dengan adanya 
dukungan sistem informasi. Melalui pengabdian kepada masyarakat ini diharapkan dapat meningkatkan budaya dan pengetahuan pimpinan serta petugas dalam pembuatan laporan SPM GD dengan memanfaat teknologi informasi. Hal ini mendorong Prodi Rekam Medis Fakultas Kesehatan Universitas Jenderal Achmad Yani Yogyakarta untuk melaksanakan kegiatan penagbdian masyarakat dengan judul optimalisasi pelaporan standar pelayanan minimal gawat darurat berbasis teknologi informasi di RSUD Panembahan Senopati Bantul.

Tujuan umum dari kegiatan Pengabdian Kepada Masyarakat (PKM) ini adalah menciptakan budaya dan pengetahuan pengumpulan, pengolahan dan penyajian laporan SPM GD berbasis teknologi informasi sebagai bahan pembuatan laporan SPM RS dan tolak ukur kinerja pelayanan gawat darurat.

Dari tujuan umum tersebut dijabarkan sebagai berikut:

a. Memberikan penyuluhan kegiatan pengumpulan, pengolahan dan penyajian laporan SPM GD

b. Melatih petugas dalam menggunakan sistem informasi pelaporan standar pelayanan minimal gawat darurat berbasis web

c. Merancang Standar Prosedur Operasional Pelaporan SPM GD

d. Pemberian hibah aplikasi pelaporan standar pelayanan minimal gawat darurat berbasis web.

\section{Metode}

Kegiatan PKM dilaksanakan di RSUD Panembahan Senopati Bantul, yang merupakan rumah sakit tipe B milik Pemerintah Kabupaten Bantul, dan telah terkareditasi Paripurna. Lokasi PKM dilaksanakan RSUD Panembahan Senoapti Bantul berada di Jl Dr Wahidin Sudiro Husodo, Bantul, DIY. Kegiatan PKM ini melibatkan 2 orang anggota dosen dan 2 orang mahasiswa. Pelaksanaan pengabdian ini dilaksanakan dalam kurun waktu 4 (empat) bulan dari bulan September - Desember 2019.

Metode yang digunakan dalam kegiatan pengabdian kepada masyarakat ini dengan pendekatan difusi ipteks, dengan rincian kegiatan sebagai berikut:

a. Pada tahap persiapan peneliti melakukan wawancara digunakan untuk menggali permasalahan pelaporan SPM GD dan alur pelaporan, observsai digunakan untuk mengamati kegiatan pelaporan standar pelayanan minimal gawat darurat, dan studi dokumentasi pada kebijakan, formulir dan dokumen terkait pelaporan SPM GD. Dari kegiatan ini dirumuskan suatu masalah, disampaikan dalam proposal pengabdian dan dilanjutkan dengan pengurusan ijin kegiatan PKM. Proses ini berdurasi kurang lebih 2 minggu.

b. Pada tahap proses dilaksanakan:

1) Kegiatan diawali dengan penyuluhan terkait materi kegiatan pengumpulan, pengolahan dan penyajian laporan SPM GD. Selanjutnya, kegiatan dilanjutkan dengan diskusi dan tanya jawab dari peserta terkait pengumpulan data dan optimalisasi penyajian data untuk meningkatkan keakuratan pelaporan. Kegiatan tersebut berdurasi kurang lebih 3 jam.

2) Kegiatan dilanjutkan dengan agenda pelatihan penggunakan Sistem Informasi Pelaporan Standar pelayanan Minimal Gawat Darurat berbasis Web (aplikasi Spidar) mulai dari menjelaskan manual book, bisnis proses, jenis fitur, otorisasi, input data, pengiriman laporan, validasi laporan hingga cetak laporan. Peserta diberikan kesempatan untuk diskusi dan satu persatu peserta mencoba menggunakan aplikasi Spidar sesuai otorisasi masingmasing. Proses ini berdurasi kurang lebih 4 jam. 
3) Selanjutnya dilakukan kegiatan pendampingan pemanfaatan register gawat darurat yang dihasilkan dari modul gawat darurat pada Sistem Informasi sebagai bahan input data apada aplikasi Spidar. Proses ini berdurasi kurang lebih 5 jam.

4) Merancang Standar Prosedur Operasional Pelaporan SPM GD, dimulai dari format SPO, dan prosedur pengumpulan hingga penyajian laporan SPM GD. Proses ini berlangsung kurang lebih 1 minggu.

c. Pada akhir kegiatan PKM ini dilakukan pemberian hibah aplikasi pelaporan standar pelayanan minimal gawat darurat berbasis web dan pendampingan instalasi pada server. Proses ini berdurasi kurang lebih 4 jam.

\section{Hasil dan Pembahasan}

Bahan atau materi yang digunakan pada kegiatan ini buku manual program, handout materi diberikan kepada seluruh staff yang hadir yang hadir saat penyuluhan. Alat yang digunakan pada kegiatan PKM ini adalah komputer atau notebook, aplikasi Pelaporan SPM GD berbasis web (Spidar), jaringan internet/Modem, LCD, sound system, kamera dan video. Sasaran kegiatan pengabdian ini adalah Pimpinan Tingkat Atas, Kepala Seksi Mutu dan Audit Klinik, Koordinator SIM RS, Kepala IGD, dan 3 staff IGD (gambar 1).

Secara keseluruhan, kegiatan pengabdian masyarakat ini berjalan dengan lancar. Sambutan dari seluruh petugas rumah sakit juga sangat baik, ramah, dan bekerjasama. Antusiasme dari peserta juga cukup baik, hal ini bisa terlihat mulai dari awal kegiatan sampai rangkaian kegiatan selesai.

Kegiatan penyuluhan dan pelatihan dibuka oleh mahasiswa sebagai MC. Mahasiswa lain bertugas mendokumentasikan kegiatan. Pemberian sambutan dilakukan oleh Kepala IGD, yang menyampaikan ucapan terimakasih tas penyelenggaraan kegiatan penyuluhan dan pelatihan. Hal ini dikarenakan materi yang akan disampikan sangat penting dan mendapat manfaat praktis. Selanjutnya ketua tim PKM memperkenalkan seluruh anggota PKM, serta maksud dan tujuan kegiatan PKM.

Materi pertama pada kegiatan PKM ini adalah ketua PKM memberikan materi penyuluhan terkait kegiatan pengumpulan, pengolahan dan penyajian laporan SPM GD. Peeserta cukup antusias menyimak materi penyuluhan (Gambar.1).

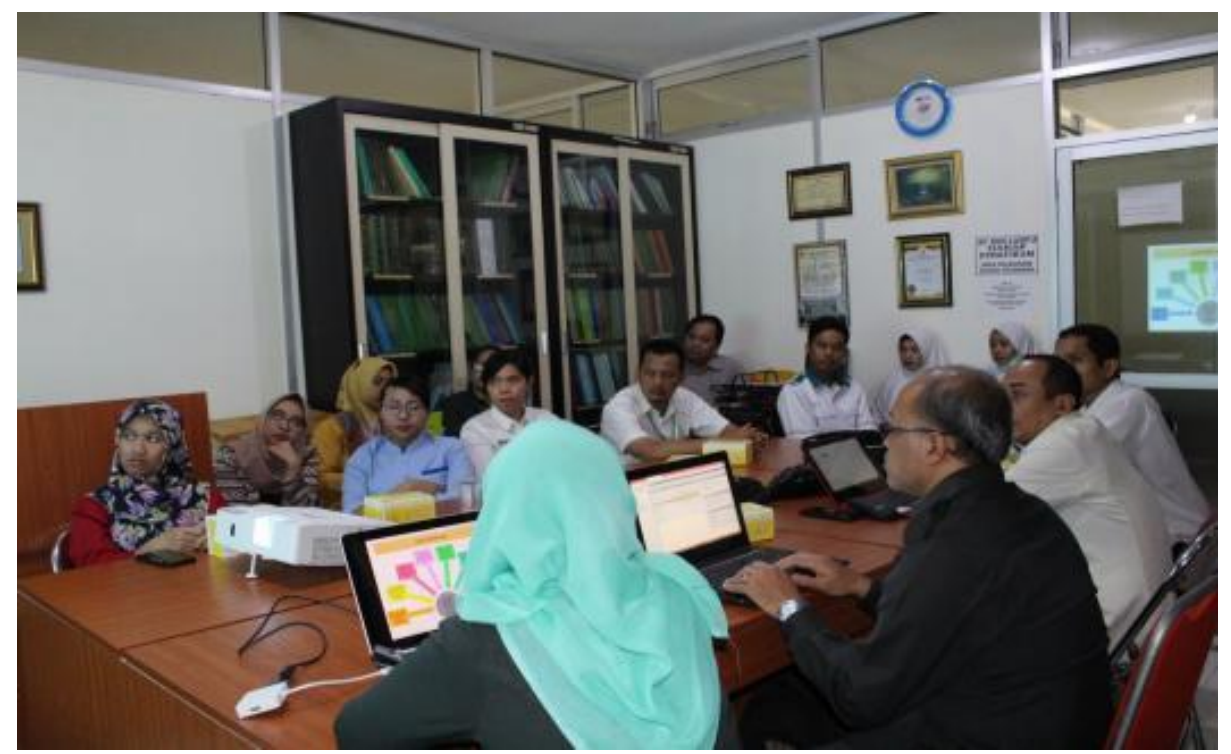

Gambar 1. penyampaian materi dari Ketua PKM 
Selanjutnya, kegiatan dilanjutkan dengan diskusi dan tanya jawab dari peserta terkait pengumpulan data dan optimalisasi penyajian data untuk meningkatkan keakuratan pelaporan. Kegiatan dilanjutkan dengan agenda pelatihan penggunakan Sistem Informasi Pelaporan Standar pelayanan Minimal Gawat Darurat berbasis Web (aplikasi Spidar) mulai dari menjelaskan manual book, bisnis proses, jenis fitur, otorisasi, input data, pengiriman laporan, validasi laporan hingga cetak laporan.

Tingginya kebutuhan data dan kesehatan yang komples menjadi salah satu dasar bahwa sistem informasi memainkan peran yang cukup besar dan berpengaruh karena pengembangan SIM RS RS dapat meningkatkan kecepatan, keakuratan, dan kecepatan identifikasi masalah serta memudahkan pada saat penyusunan strategi di lingkungan manajerial [8], [9]. Kepala IGD juga dilatih untuk membuat master data, username dan pasword bagi petugas lain yang berhak mengakses aplikasi Spidar. Adanya pembatasan akses ini bertujuan untuk menjaga keamanan data dalam hal integritas (integrity), dimana data tidak boleh diubah tanpa ijin dari yang berhak[10]. Berikut menu utama/beranda aplikasi Spidar (Gambar 2):

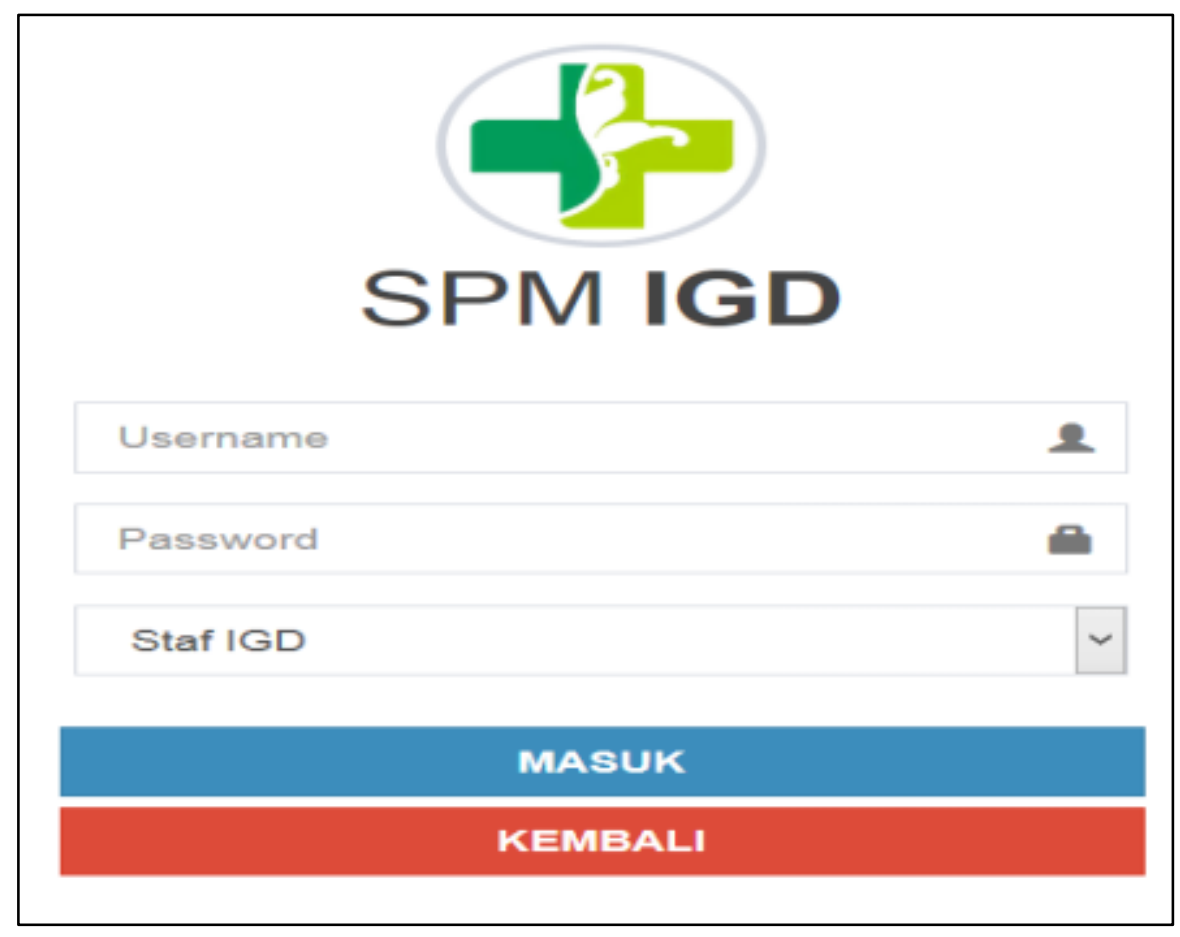

Gambar 2. Halaman Beranda dan Log in

Berdasarkan Gambar 2. menunjukkan halaman Beranda dan login. Jika login berhasil maka sistem akan menampilkan halaman menu utama sesuai dengan hak akses (otorisasi) dari masing-masing pengguna. Salah satu mekanisme dasar yang hars dipenuhi untuk memastikan aspek keamanan dan keberlangsungan sistem dengan adanya mekanisme autentikasi dan otorisasi. Adanya halaman log in dan log out pada apliaksi Spidar juga menunjukkan adanya fungsi confidentiality dalam upaya menjaga keamanan dari sistem. Confidentiality merupakan batasan akses terhadap data/informasi yang dibatasi hanya bagi mereka yang punya otoritas[10]. 


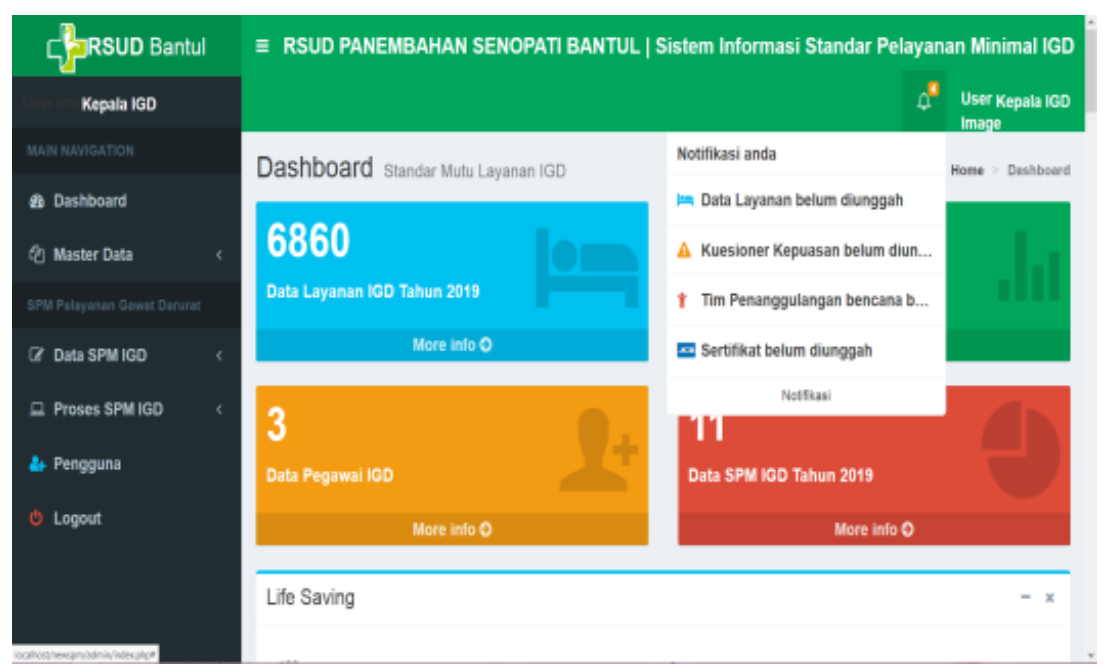

Gambar 3. Aplikasi Spidar

Pada Gambar 3 menunjukkan pada aplikasi Spidar sudah dilengkapi dengan notifikasi, sehingga mempermudah pengguna menerima pesan terkait kelengkapan data dari laporan SPM GD. Fitur notifikasi berfungsi sebagai pesan sehingga pencarian data akan menjadi lebih mudah [11].

Untuk meningkatkan animo peserta, maka satu persatu peserta diberikan kesempatan mencoba menggunakan aplikasi Spidar sesuai otorisasi masingmasing (Gambar 4).

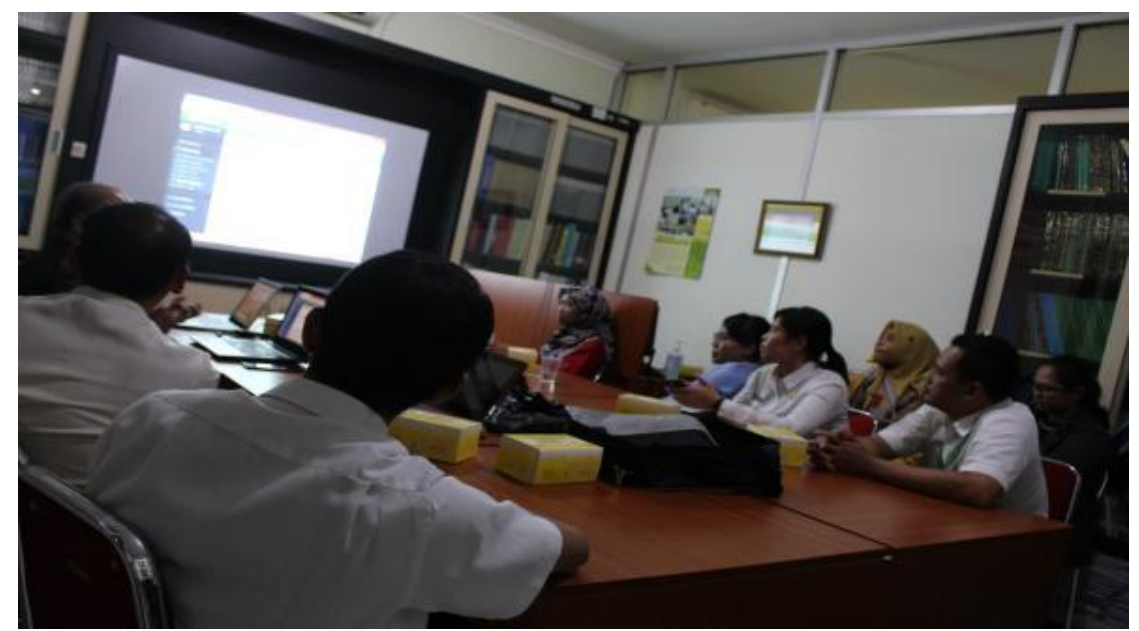

Gambar 4. Peserta mencoba menggunakan aplikasi Spidar

Selanjutnya dilakukan kegiatan pendampingan pemanfaatan register gawat darurat yang dihasilkan dari modul gawat darurat pada Sistem Informasi sebagai bahan input data pada aplikasi Spidar. Berikut gambaran hasil input data pada apliaksi Spidar dengan menggunakan menu import data register gawat darurat dari SIRS (Gambar 5):

Pada Gambar 5. menunjukkan halaman data entry untuk menginput data. Hal ini menunjukkan bahwa aplikasi Spidar dapat berfungsi sebagai data sharing, yaitu memungkinkan terjadinya pemakaian secara bersama-sama dan berbagi data dalam sebuah sistem. Karena data yang sama akan dapat diakses oleh beberapa user pada saat bersamaan [12]. Setelah peserta mencoba melakukan simulasi penggunaan aplikasi, peserta menyadari pentingnya teknologi informasi untuk mempercepat proses pelaporan SPM GD.

Selanjutnya diberikan materi ke-3 terkait Perancangan Standar Prosedur Operasional (SPO) Pelaporan SPM GD, dimulai dari format SPO, dan prosedur 
pengumpulan hingga penyajian laporan SPM GD. SPO merupakan serangkaian instruksi tertulis yang dibakukan mengenai berbagai proses penyelenggaraan administrasi pemerintahan, bagaimana dan kapan harus dilakukan, dimana dan oleh siapa dilakukan [13]. Kegiatan yang memerlukan SPO adalah kegiatan yang dilaksanakan secara rutin atau berulang-ulang, menghasilkan suatu output dan dalam pelaksnaannya melibatkan minimal dua orang [14].

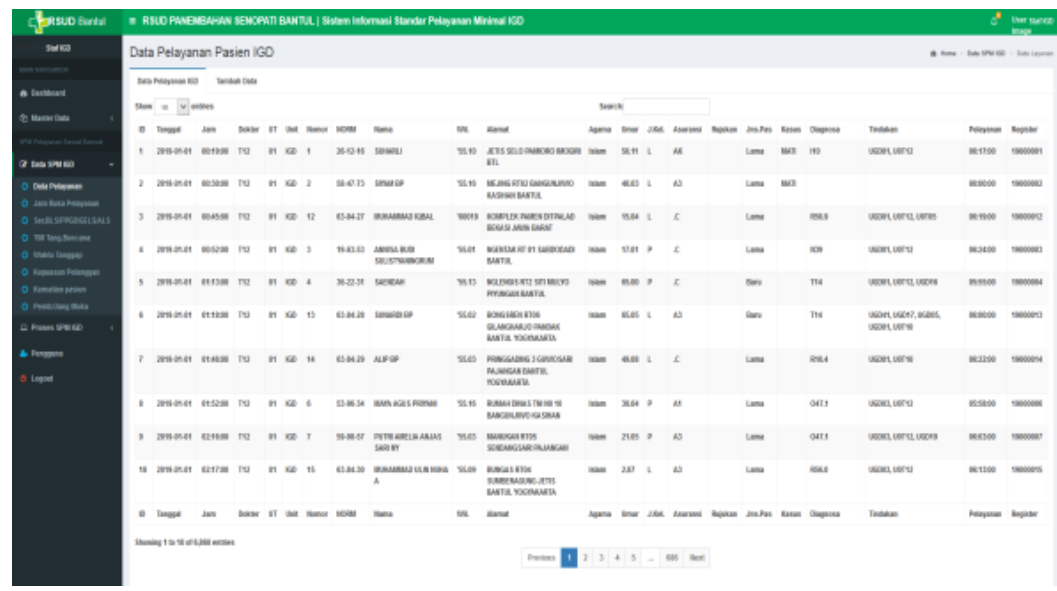

Gambar 5. Input data dengan menu import

Dalam sesi pelatihan, peserta cukup antusias untuk berdiskusi, peserta menanyakan proses bisnis, otorisasi data dan kemungkinan pengembangan modul dari aplikasi Spidar. Dengan demikian diharapkan petugas/user yang akan menggunakan aplikasi tersebut menjadi lebih siap dan terlatih. Disamping mengikuti pelatihan, disediakan pula doorprize bagi petugas IGD yang aktif dalam kegiatan tersebut.

Diakhir kegiatan PKM ketua Tim melakukan serah terima aplikasi Standar Pelayanan Minimal Berbasis Web (aplikasi Spidar) kepada Kepala IGD RSUD Panembahan Senopati Bantul (gambar 6), dan pendampingan instalasi aplikasi pada server rumah sakit.

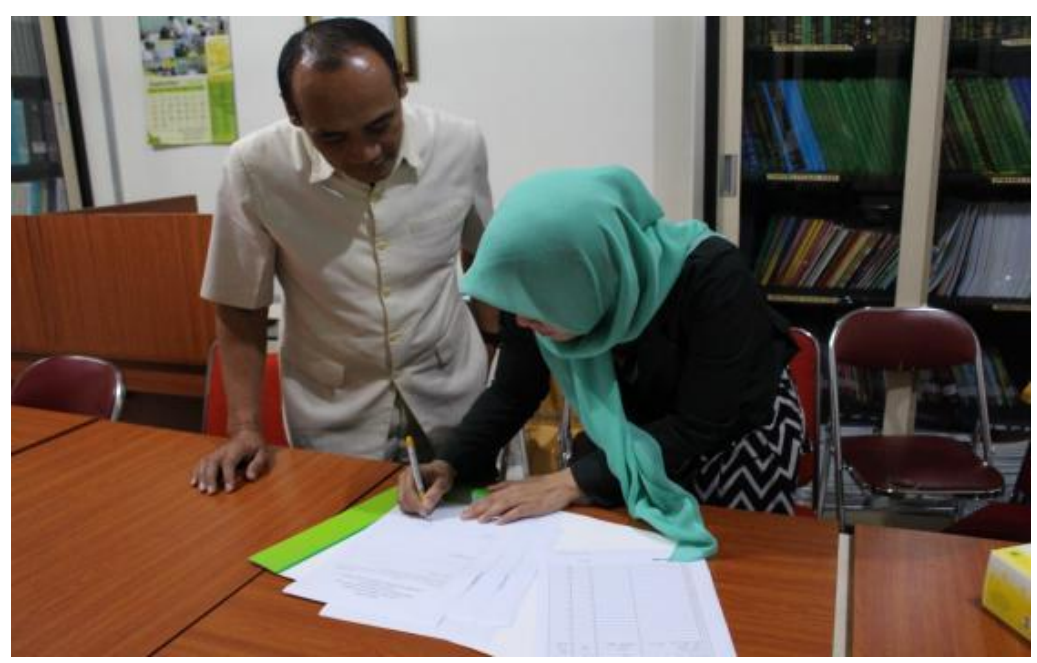

Gambar 6. Penandatanganan Berita Acara serah terima aplikasi Spidar

Selanjutnya acara ditutup dengan foto bersama di ruang gawat darurat RSUD Panembahan Senopati Bantul (Gambar 7). 


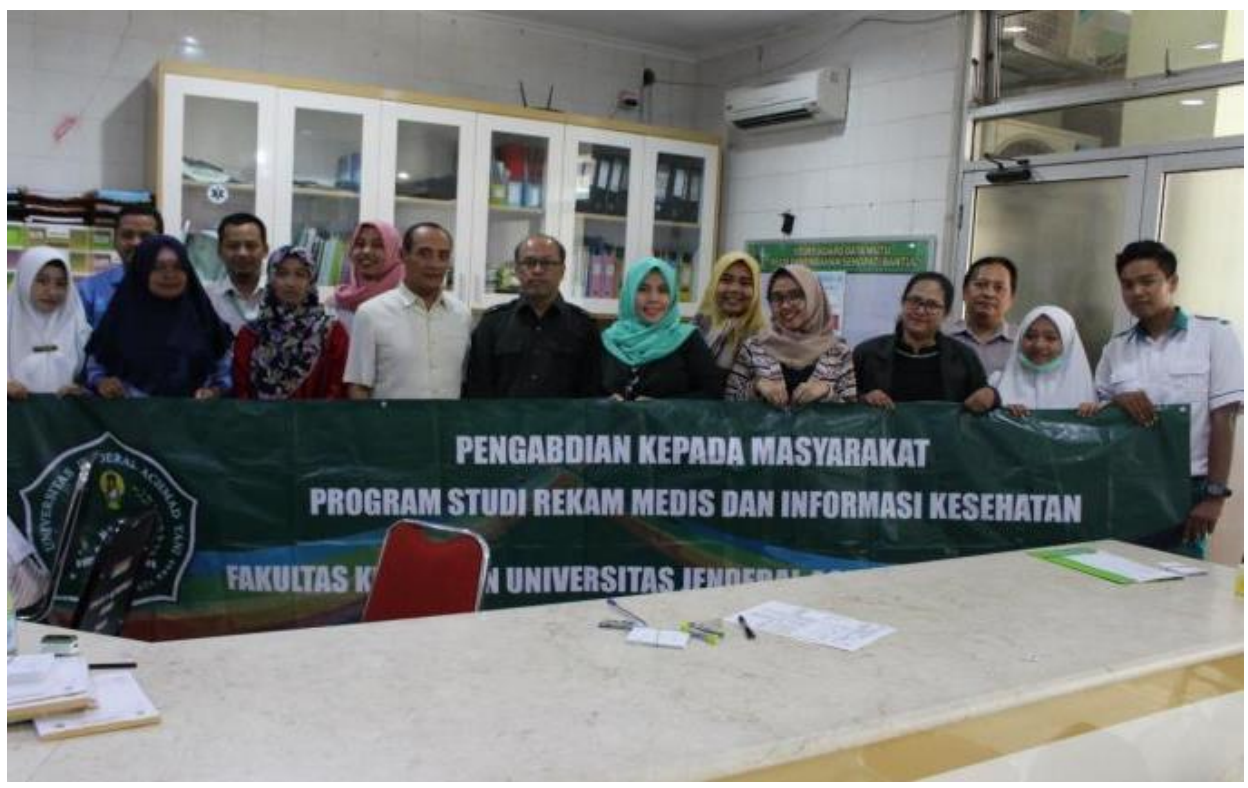

Gambar 7. Foto bersama kegiatan PKM

\section{Kesimpulan}

Kegiatan penyuluhan dan pelatihan berjalan lancar. Pada awalnya, register gawat darurat yang dihasilkan dari Sistem Informasi Rumah Sakit tidak dimanfaatkan sebagai bahan pengumpulan data SPM GD. Setelah dilakukan penyuluhan dan pelatihan, petugas akhirnya menyadari pentingnya pemanfaatan teknologi informasi untuk meningkatkan kualitas pelaporan SPM GD pada aspek ketersediaan, kemudahan, kesesuaian, kelengkapan dan ketepatan waktu dalam rangka meningkatkan efektifitas alur kerja petugas, kemudahan mengakses informasi, dan penyimpanan data terpusat pada manajamen basisdata.

Kegiatan pengabdian masyarakat seperti ini perlu dilanjutkan dan dikembangkan. Hal ini dikarenakan keberhasilan pelaporan SPM GD berbasis teknologi informasi salah satunya adalah adanya kepatuhan petugas dalam melakukan input data untuk menghasilkan output sesuai harapan pengguna. Pelatihan dan pendampingan kepada petugas sebaiknya dilakukan secara kontinue sehingga petugas benar-benar terampil melakukan input data dengan lengkap untuk mendukung pelaporan SPM GD yang akurat.

\section{Ucapan terima kasih}

Terimakasih kepada Universitas Jenderal Achmad Yani Yogyakarta yang telah memberikan dukungan atas kegiatan PKM ini.

\section{Daftar pustaka}

[1] Kemendagri, Peraturan Menteri Kesejatan RI no 61 Tahun 2007 Tentang Pedoman Teknis Pengelolaan Keuangan Badan Layanan Umum Daerah. Jakarta, 2007, pp. 1-13.

[2] KARS, "Standar Nasional Akreditasi Rumah Sakit Edisi 1," 1st ed., Jakarta: KARS, 2017, pp. 1-421.

[3] Kemenkes RI, Peraturan Menteri Kesehatan Republik Indonesia nomor: 129/Menkes/SK/II/2008 Tentang Standar Pelayanan Minimal Rumah Sakit. 2008.

[4] Kori Puspita Ningsih et.al, "The Planning Of Technology-Based Emergency Minimum Service Standard Reporting System,” Int. J. Heal. 
Educ. Soc., vol. 2, no. 9, p. 36, 2019.

[5] K. C.Laudon and J. P. Laudon, Management Information System (Mengelola Perusahaan Digital), 10th ed. Jakarta: Salemba Empat, 2007.

[6] F. Hakam, N. Alis Setiyadi, and N. A. Setiyadi, "Pengembangan Sistim Pencatatan Dan Pelaporan Data Di Klinik Muhammadiyah Medical Center," J. Kesehat. Masy. Andalas, vol. 8, no. 2, p. 67, 2014, doi: 10.24893/jkma.8.2.67-71.2014.

[7] Kori Puspita Ningsih et.al, "Pengembangan Pelaporan Standar Pelayanan Minimal Gawat Darurat Berbasis Web," J. Kesehat. Vokasional, vol. 4, no. 4, p. 201, 2019, doi: 10.22146/jkesvo.49165.

[8] M. Topan et al., "Perancangan Sistem Informasi Manajemen Rumah Sakit Berbasis Web Studi Kasus : Rumah Sakit TNI AU Lanud Sam Ratulangi," vol. 6, no. 1, pp. 1-6, 2015.

[9] Kemenkes, "Permenkes RI Nomor 82 Tahun 2013 tentang Sistem Informasi Manajamen Rumah Sakit," no. 87, pp. 1-36, 2013.

[10] Kemenkominfo, Permenkominfo No 41/Per/Men.Kominfo/11/2007 tentang Panduan Umum Tata Kelola Teknologi Informasi dan Komunikasi Nasional. Jakarta, 2007, pp. 1-49.

[11] R. Rusdiansyah, "Membangun Prototype Sistem Informasi Arsip Elektronik Surat Perjanjian Kerjasama Pada Business Support Departemenr," J. PILAR Nusa Mandiri, vol. 14, no. 2, pp. 157-162, 2018, doi: 10.33480/pilar.v14i2.903.

[12] F. Hakam, Analisis, Perancangan dan Evaluasi Sistem Informasi Kesehatan. Yogyakarta: Gosyen Publishing, 2016.

[13] Rara Sabrina Dukma dan Siswati, "Tinjauan Pelaksanaan Standar Prosedur Operasional Distribusi Rekam Medis Rawat Jalan Di Rumah Sakit Umum Daerah Kota Bekasi," Jurna INOHIM, vol. 5, no. 2, pp. 125-129, 2017.

[14] R. Nindyakinanti and S. C. Budi, "Sistem Penyimpanan dan Pemrosesan Rekam Medis Terkait Standar Akreditasi Kriteria 8.4.3 di Puskesmas Jetis 1 Bantul," J. Kesehat. Vokasional, vol. 1, no. 2, p. 94, 2017, doi: 10.22146/jkesvo.27575. 